\title{
COMMERCIAL ARBITRATION
}

The Scottish and International Perspectives 



\title{
COMMERCIAL ARBITRATION
}

The Scottish and International Perspectives

\author{
HONG-LIN YU, Ph.D. \\ Reader in Law, University of Stirling
}

DUNDEE UNIVERSITY PRESS

2011 


\author{
Published in Great Britain in 2011 by \\ Dundee University Press \\ University of Dundee \\ Dundee DD1 4HN \\ www.dundee.ac.uk/dup \\ Copyright (C) Hong-Lin Yu \\ ISBN 978-1-84586-107-0
}

All rights reserved. No part of this publication may be reproduced, stored or transmitted in any form, or by any means, electronic, mechanical or photocopying, recording or otherwise, without the express written permission of the publisher.

The right of Hong-Lin Yu to be identified as the author of this work has been asserted in accordance with the Copyright, Designs and Patents Act 1988.

To avoid distraction to the reader, DUP's house style invokes the Interpretation Act 1978, so that the maculine forms "he", "him" and "his" are used throughout: all such references are intended to be read as gender-neutral.

No natural forests were destroyed to make this product; only farmed timber was used and replanted

British Library Cataloguing-in-Publication data

A catalogue for this book is available on request from the British Library.

Typeset by Waverley Typesetters, Warham, Norfolk

Printed by Bell \& Bain Ltd, Glasgow 